\title{
Pemodelan 2-Dimensi dan 3-Dimensi Penyebaran Bijih Besi Menggunakan Data Resistivitas dan IP di Daerah "A" Provinsi Kalimantan Selatan
}

\author{
Siva Dwi Harum ${ }^{1, \dagger}$, Tati Zera ${ }^{1}$, Dwi Haryanto ${ }^{2}$ \\ ${ }^{1}$ Program Studi Fisika, Fakultas Sains dan Teknologi, Universitas Islam Negeri Syarif Hidayatullah \\ Jakarta, Jalan. Ir. H. Djuanda No.95, Cempaka Putih, Ciputat, Kota Tangerang Selatan, Banten 15412, \\ Indonesia \\ ${ }^{2}$ Pusat Teknologi Bahan Galian Nuklir (PTBGN) BATAN, Jalan Lebak Bulus Raya No.9 Pasar Jum'at \\ Jakarta Selatan \\ †'sivadwi9638@gmail.com
}

\begin{abstract}
Abstrak. Pulau Kalimantan, secara geologi memberikan potensi jebakan bijih besi. Bijih besi merupakan mineral yang terkandung dalam batuan sebagai bahan baku baja. Meningkatnya permintaan dunia industri terhadap mineral logam, menjadikan Indonesia bergantung pada impor. Sehingga dilakukan penelitian yang bertujuan untuk mengetahui keberadaan dan sebaran bijih besi guna memenuhi kebutuhan yang memadai. Penelitian ini dilakukan di daerah "A" Provinsi Kalimantan Selatan menggunakan data resistivitas dan data Induced Polariation (IP) dengan konfigurasi Wenner yang terdiri dari 23 lintasan. Induced Polarization atau Polarisasi terimbas merupakan salah satu metode geolistrik yang sangat efektif untuk mengidentifikasi keberadaan mineral di bawah permukaan. Pengolahan data dawali dengan proses inversi 2-Dimensi untuk mendapatkan nilai resistivitas dan chargeability yang sebenarnya hingga mendapatkan model 3-Dimensi dengan berbagai irisan secara vertikal dan horisontal. Berdasarkan pemodelan, diduga keberadaan bijih besi ditemukan pada 16 lintasan diantaranya lintasan Q, P, O, V, M, V, L, K, W, J, I, H, G, F, E, dan D yang ditandai dengan rentang nilai resistivitas berkisar antara 85,5-1246 $\Omega \mathrm{m}$ dan rentang nilai chargeability berkisar antara 4,5-16,1 msec. Penyebaran bijih besi di daerah "A" Provinsi Kalimantan Selatan mengarah ke timur laut.
\end{abstract}

Kata Kunci: Metode Geolistrik, Induced Polarization, bijih besi, resistivitas, chargeability

\begin{abstract}
Kalimantan, geologically provides a potential iron ore. Iron ore is a mineral contained in rock as a raw material for steel. Increasing industrial demand for metal minerals makes Indonesia dependent on imports. This research is conducted to find out the existence and distribution of iron ore to meet adequate needs. This research was carried out at "A" area of South Kalimantan Province using resistivity data and IP data with Wenner array consisting of 23 tracks. Induced Polarization is one of the most effective geoelectric method to identify the presence of minerals beneath the surface. Data processing is initiated by a 2-Dimensional inversion process to obtain the true resistivity and true chargeability values to obtain a 3-Dimensional model with various slices vertically and horizontally. Based on the modeling, the presence is found in 16 traps including the $Q, P, O, N, M, V, L, K, W, J, I, H, G, F, E$, and $D$ traps which have resistivity value ranging between 85,5-1246 $\Omega m$ and chargeability value ranging between 4,5-16,1 mses. Distribution of iron ore in the area of the province of South Kalimantan leads to the northeast.
\end{abstract}

Keywords: Geoelectric method, Induced polarization, iron ore, resistivity, chargeability

\section{PENDAHULUAN}

Kemajuan ilmu pengetahuan dan teknologi mengalami peningkatan akan kebutuhan logam dasar sehingga menuntut untuk tersedianya bahan baku yang memadai. Salah satu bahan baku utama yang banyak digunakan dalam industri logam yaitu bijih besi. Guna memenuhi kebutuhan akan bijih besi perlu dilakukan eksplorasi untuk mencari jebakan mineral baru. Jebakan mineral yang dibutuhkan yaitu endapan yang mengandung bahan atau material ekonomis. Salah satu daerah yang memiliki potensi bijih besi di Indonesia adalah Provinsi Kalimantan Selatan. Penelitian ini berada di daerah "A" Provinsi Kalimantan Selatan dimana lokasi penelitian ini berada di antara formasi keramaian (kak) dan batuan malihan (Mm). Formasi Keramaian merupakan perselingan batupasir, batulanau, dan batulempung sedangkan batuan Malihan (Mm) memiliki hubungan kontak tektonik dengan batuan disekitarnya [1]. Berdasarkan hasil survei 
sebelumnya, telah dilakukan pengolahan data untuk mendapatkan pemodelan 2-Dimensi dan 3Dimensi sehingga dapat mengetahui keberadaan dan penyebaran bijih besi pada daerah penelitian.

Pada survei di lapangan menggunakan metode geofisika yaitu metode geolistrik yang mempelajari sifat aliran listrik di dalam bumi dan mendeteksinya di permukaan bumi. Ada beberapa macam metode geolistrik, diantaranya metode resistivitas dan metode Induced Polarization. Prinsip dasar dalam kedua metode tersebut yaitu menginjeksikan arus listrik ke dalam bumi menggunakan elektroda arus yang kemudian di ukur beda potensialnya menggunakan elektroda potensial. Pengukuran resistivitas didasari oleh Hukum Ohm yang menemukan hubungan antara arus (I) dengan beda potensialnya (V). Berdasarkan nilai arus dan beda potensial tersebut dapat diketahui nilai resistansinya yang dirumuskan sebagai berikut [2].

$$
\rho_{a}=K \frac{\Delta V}{I}
$$

Dimana K merupakan faktor geometri yang besarnya bergantung pada susunan elektroda (konfigurasi). Konfigurasi yang digunakan pada survei di lapangan yaitu konfigurasi wenner.

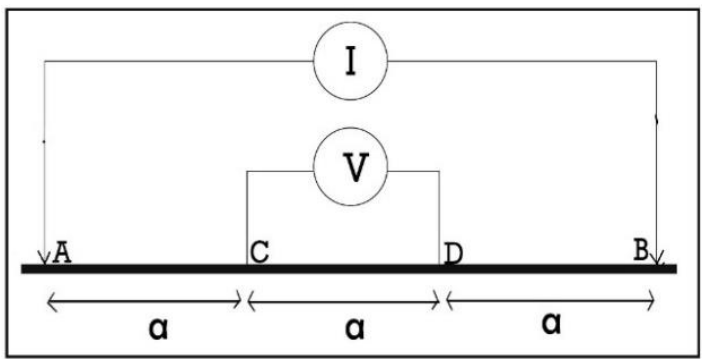

Gambar 1. Susunan elektroda konfigurasi wenner

Pada konfigurasi Wenner $\mathrm{AC}=\mathrm{CD}=\mathrm{DB}=$ a yang merupakan jarak antara kedua elektroda arus dan elektroda potensial. Sehingga faktor geometri dalam konfigurasi ini dapat dirumuskan sebagai berikut

$$
K=\frac{2 \pi}{\left[\left(\frac{1}{r 1}-\frac{1}{r 2}\right)-\left(\frac{1}{r 3}-\frac{1}{r 4}\right)\right]} .
$$

Metode Induced Polarization ini mengamati efek polarisasi yang terjadi setelah arus listrik dimatikan sehingga metode ini sangat efektif digunakan untuk mengidentifikasi batuan yang mengandung deposit mineral. Efek polarisasi yang ditimbulkan dapat disebabkan oleh polarisasi membran dan polarisasi elektroda. Polarisasi membran disebabkan oleh menyempitnya pori-pori akibat keberadaan partikel lempung (clay) yang umumnya bermuatan negative yang sangat besar menyebabkan ion-ion positif pada fluida elektrolit tertarik ke arah partikel lempung yang bermuatan negatif. Proses ini menimbulkan awan-awan positif (membran) pada sisi pori-pori batuan. Sedangkan polarisasi elektroda disebabkan oleh keberadaan mineral logam pada batuan yang menghalangi aliran arus saat melewati batuan sehingga akan terjadi reaksi kimia pada bidang batas mineral logam yang menimbulkan potensial ekstra atau overvoltage. Ketika arus listrik dimatikan, ion-ion akan terakumulasi kembali ke posisi semula dan polarisasi elektroda meluruh secara berangsung-angsur terhadap waktu.

Perhitungan peluruhan potensial ketika arus diinjeksikan lalu dimatikan dan saat potensial meluruh sempurna akan menghasilkan nilai chargeability semu yang secara sistematis harga chargeability semu dituliskan sebagai berikut [3].

$V o=$ Beda potensial saat arus dialirkan

$$
M=\frac{1}{V_{0}} \int V_{t}(t) d t
$$

$V t=$ Beda potensial sesaat setelah arus terputus

Untuk menentukan anomali bijih besi di bawah permukaan pada daerah penelitian dapat dilakukan melalui analisis dan interpretasi data yang telah diolah hingga menghasilkan pemodelan berupa model 2-Dimensi dan 3-Dimensi. Dalam analisis dan interpretasi di lapangan dilakukan dengan membandingkan nilai resistivitas dan chargeability yang mengacu pada referensi sebagai berikut. 


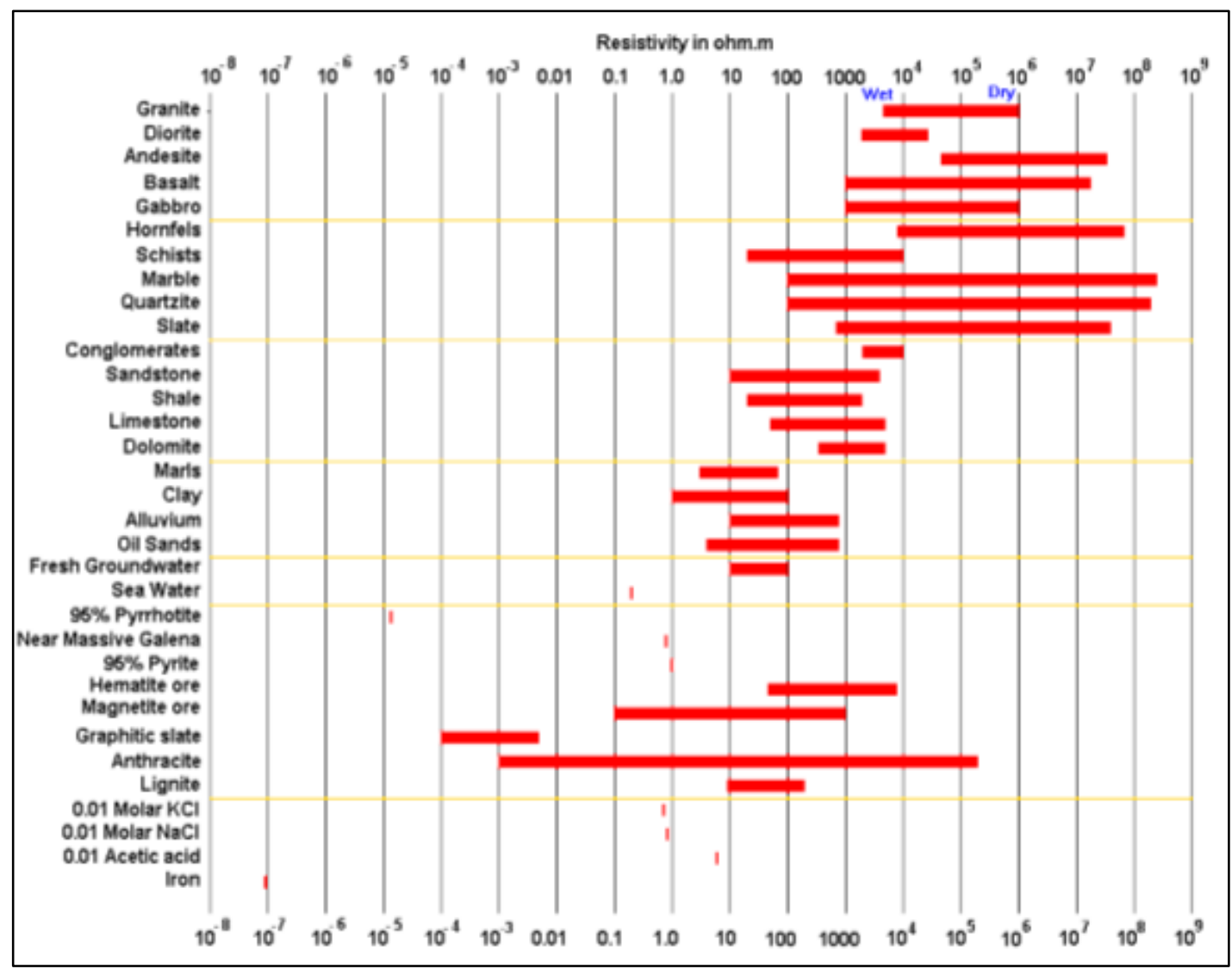

Gambar 2. Nilai Resistivitas Material [4]

Tabel 1. Nilai Chargeability Mineral [5]

\begin{tabular}{cc}
\hline Mineral & Chargeability (msec) \\
\hline Pyrite & 13,4 \\
Chalcocite & 13,2 \\
Copper & 12,3 \\
Graphite & 11,2 \\
Chalcopyrite & 9,4 \\
Bornite & 6,3 \\
Galena & 3,7 \\
Magnetite & 2,2 \\
Malachite & 0,2 \\
Hematite & 0,0 \\
\hline
\end{tabular}

Tabel 2. Nilai Chargeability Beberapa Mineral dan Batuan [5]

\begin{tabular}{ll}
\hline \multicolumn{1}{c}{ Material } & \multicolumn{1}{c}{ Chargeability (msec) } \\
\hline $20 \%$ Sulfides & $2.000-3.000$ \\
$8 \%-20 \%$ Sulfides & $1.000-2.000$ \\
$2 \%-8 \%$ Sulfides & $500-1.000$ \\
Volcanic Tuffs & $300-800$ \\
Sandstone, Siltstone & $100-500$ \\
Shale & $50-100$ \\
Granite & $10-50$ \\
Limestone, Dolomite & $10-20$ \\
\hline
\end{tabular}

\section{METODOLOGI PENELITIAN}

Penelitian dilakukan di daerah "A" Provinsi Kalimantan Selatan menggunakan data resistivitas dan data IP dengan konfigurasi Wenner. Titik pengukuran pada hasil survei terdiri dari 
23 lintasan dengan luas daerah penelitian 1000 x 1000 meter. Setiap lintasan memiliki jarak yang berbeda-beda dan jarak masing-masing elektrodanya sejauh 25 meter. Dalam penelitian "Pemodelan 2-Dimensi dan 3-Dimensi Penyebaran Bijih Besi Menggunakan Data Resistivitas dan IP di Daerah "A" Provinsi Kalimantan Selatan" ini meliputi beberapa tahapan. Berikut merupakan diagram alir penelitian.

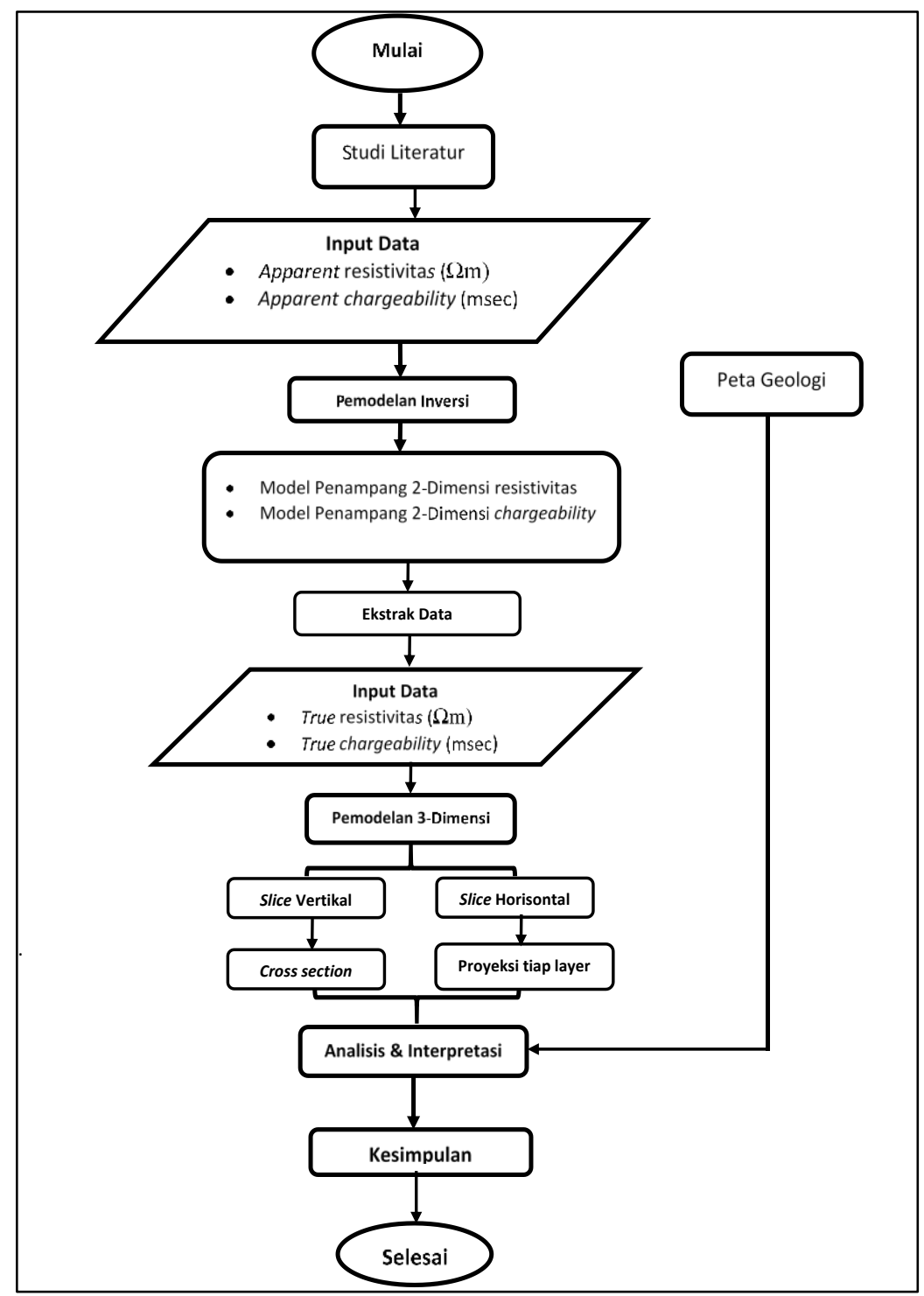

Gambar 4. Diagram alir penelitian

Data yang diperoleh, kemudian diolah hingga menghasilkan pemodelan 2-Dimensi dengan menggunakan software RES2DINV dan pemodelan 3-Dimensi menggunakan software Voxler 4. Pada pemodelan 3-Dimensi akan divisualisasikan ke dalam beberapa macam model irisan baik secara vertikal dan horizontal serta model irisan tiap layer berdasarkan elevasinya. Hal tersebut dilakukan untuk mempermudah proses analisis dan interpretasi terutama untuk mengetahui penyebaran bijih besi pada daerah penelitian.

Untuk mengindikasi keberadaan bijih besi di daerah penelitian ditunjukkan dengan nilai resistivitas rendah dan chargeability yang tinggi [6] . Seluruh hasil pengolahan data tiap lintasan kemudian diinterpretasikan nilai anomali resistivitas dan chargeability dengan mengkorelasikan nilai referensi (Gambar 3, Tabel 1, Tabel 2) dan kondisi geologi daerah tersebut. 


\section{HASIL DAN PEMBAHASAN}

Hasil pengolahan data, menghasilkan sebanyak 23 lintasan yang setiap lintasannya terdiri dari penampang resistivitas dan penampang chargeability. Penampang resistivitas tersebut memvisualisasikan rentang nilai berkisar antara 85,5-4146 $\Omega \mathrm{m}$ dan rentang nilai untuk chargeability-nya berkisar antara -24,5-16,1 msec. Berikut merupakan rentang nlai resistivitas dan chargeability penampang model 2-Dimensi dari semua lintasan.

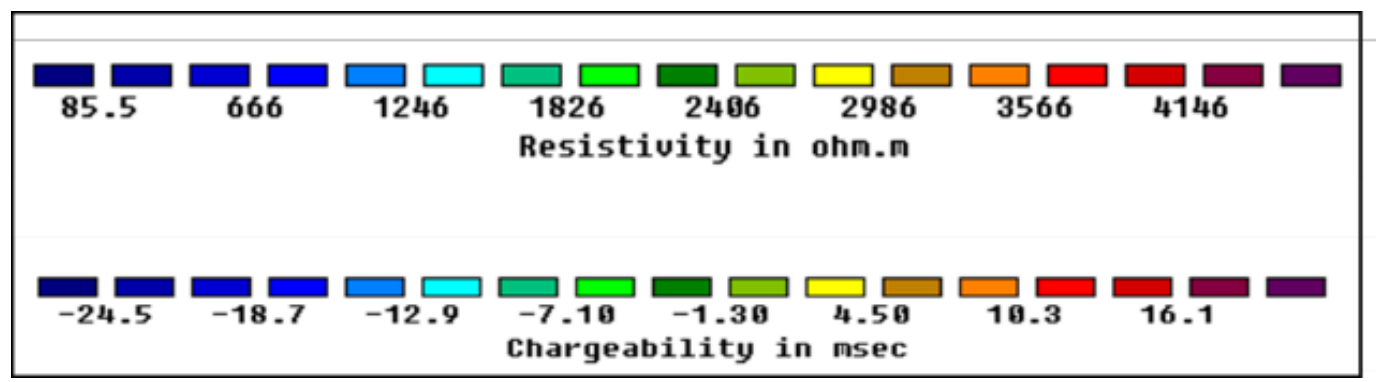

Gambar 5. Rentang nilai resistivitas dan chargeability

Berikut merupakan beberapa lintasan hasil pemodelan 2-Dimensi yang telah di inversi menggunakan software RES2Dinv.

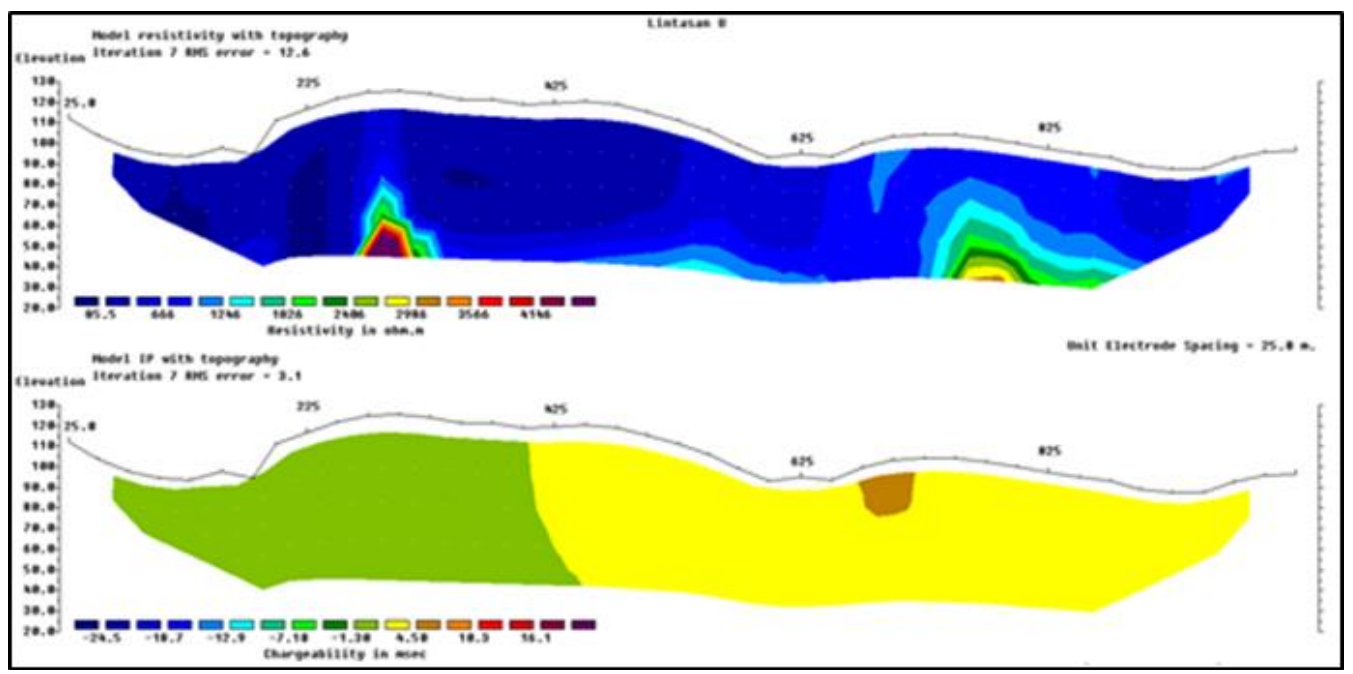

Gambar 6. Pemodelan 2-Dimensi Lintasan U

Pada lintasan U terbentang sepanjang 925 meter dengan elevasi 29,97 meter hingga 116,87 meter di atas permukaan yang memiliki 41 titik pengukuran. Titik pengukuran awal terletak pada titik 62,5 meter hingga 987,5 meter dengan permukaan yang sedikit bergelombang. Berdasarkan model (Gambar 6) menunjukkan tidak ada warna yang kontras antara kedua penampang sehingga diduga lintasan $\mathrm{U}$ tidak berpotensi mengandung bijih besi. 


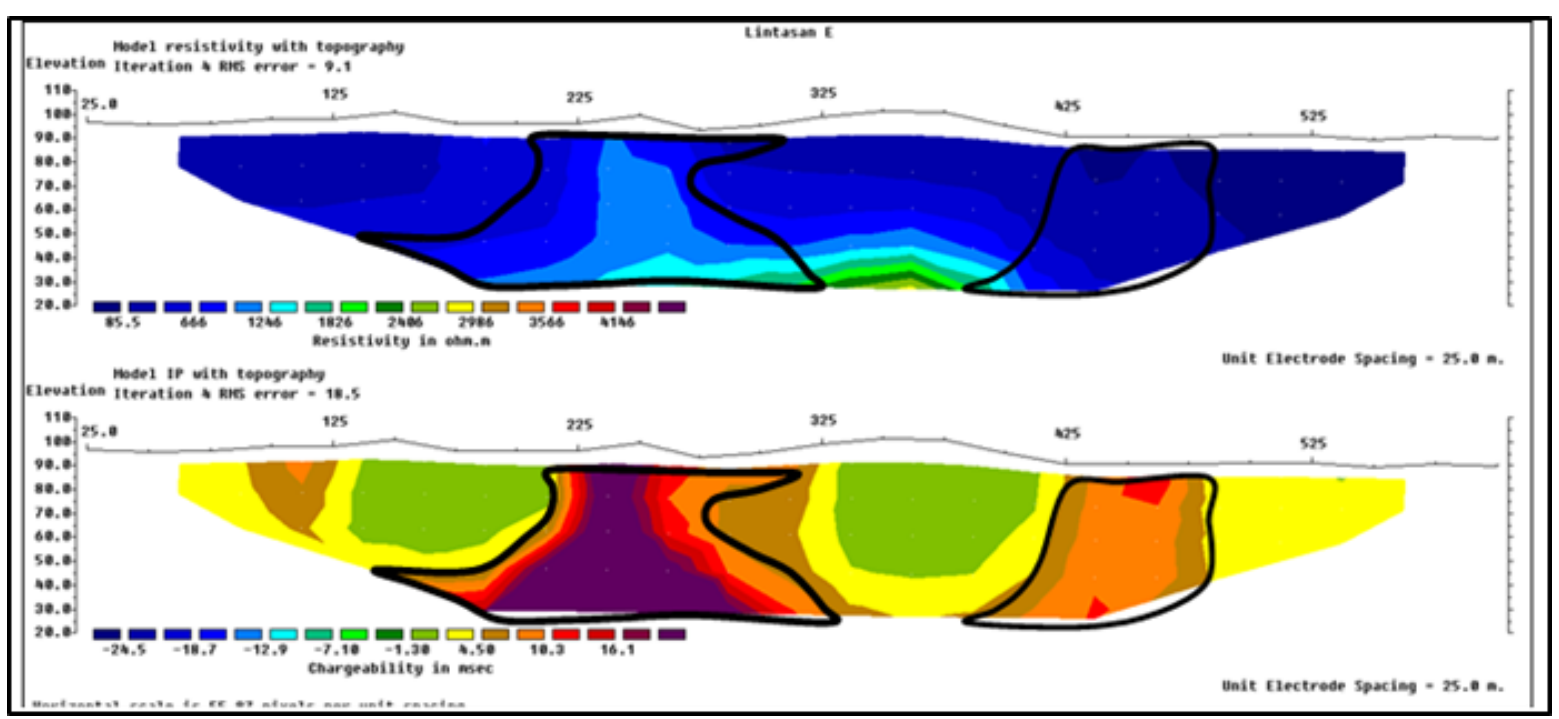

Gambar 6. Pemodelan 2-Dimensi Lintasan E

Pada lintasan E diduga ditemukan dua buah anomali bijih besi. Titik pertama yang terindikasi mengandung bijih besi berada pada bentangan 137,5-312,5 meter dengan elevasi pada 28-92,5 meter di bawah permukaan ditandai dengan rentang nilai resistivitas berkisar antara 85,5$1246 \Omega \mathrm{m}$ dan rentang nilai chargeability berkisar antara 10,3-16,1 msec. Sedangkan titik anomali bijih besi kedua berada pada bentangan 375-800 meter dengan elevasi sekitar 26-87 meter di bawah permukaan yang memiliki rentang nilai resistivitas berkisar antara 85,5-1246 $\Omega \mathrm{m}$ dan rentang nilai chargeability berkisar antara 4,5-16,1 msec. Berdasarkan pemodelan 2-Dimensi semua lintasan, didapatkan nilai true resistivitas dan true chargeability yang digunakan untuk membuat pemodelan 3-Dimensi. Pemodelan 3-Dimensi ini dilakukan menggunakan software Voxler 4, sehingga didapatkan bentuk solid model yang merupakan gabungan dari seluruh lintasan.

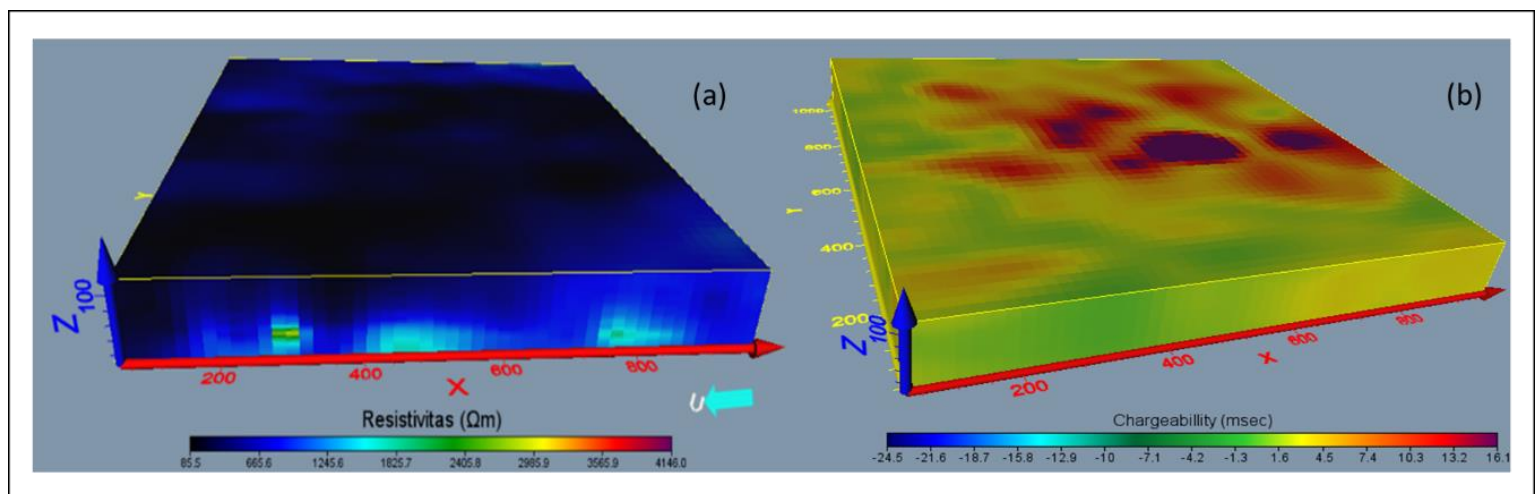

Gambar 7. Model 3-Dimensi resistivitas (a). Model 3-Dimensi chargeability

Gambar 7 mmenunjukkan pemodelan 3-Dimensi dari data resistivitas dan chargeabilitynya. Namun, kekurangan dari model di atas yaitu tidak dapat menampilkan bagian dalam dari model sehingga perlu dilakukan pengirisan secara vertikal. Irisan vertikal yang membagi antara utara-selatan dan barat-timur yang kemudian digabungkan hingga membentuk cross section (Gambar 8). Pengirisan pun juga dilakukan pada model chargeability-nya sehingga menghasilkan pemodelan seperti gambar berikut. 


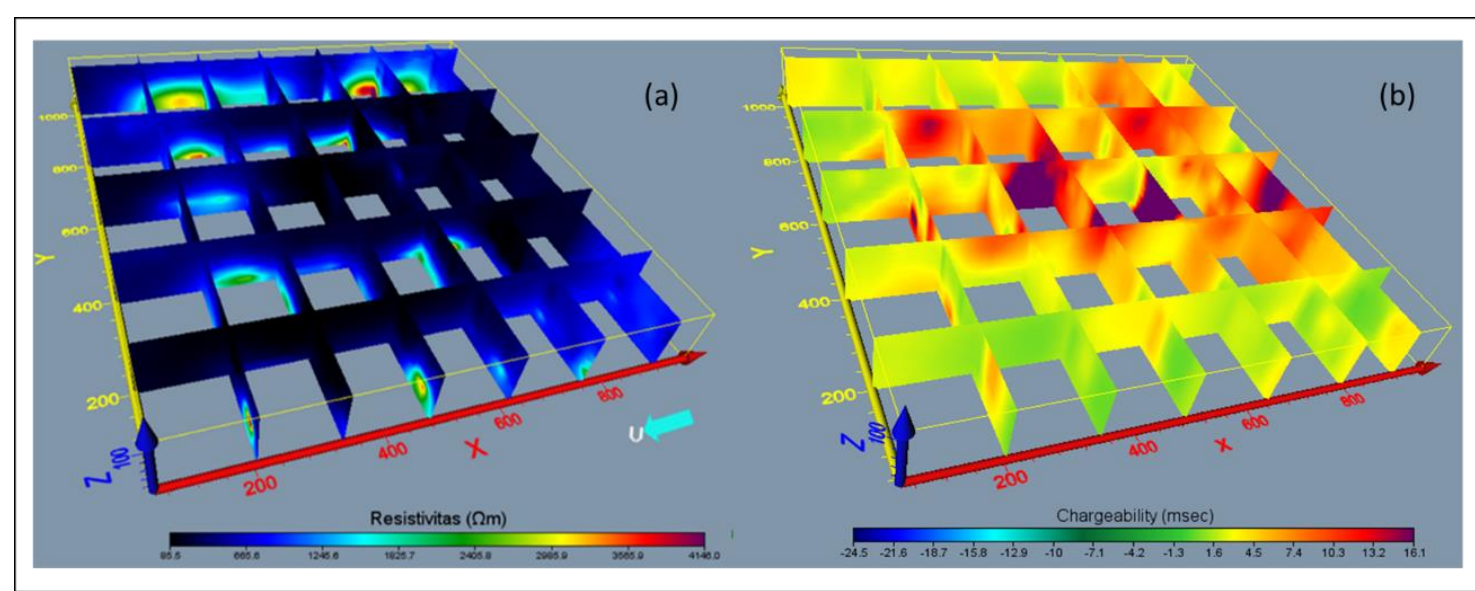

Gambar 8. Model crossection resistivitas (a) cross section chargeability (b)

Pada pemodelan 3-Dimensi keberadaan bijih besi di representasikan dengan warna biru tua hingga biru muda dengan rentang nilai resistivitas berkisar antara 85,5-1246 $\Omega \mathrm{m}$. Namun untuk memastikan penyebaran yang lebih akurat diperlukan dukungan model 3-Dimensi chargeability. Berdasarkan cross section chargeability terlihat beberapa daerah yang memiliki warna kontras terhadap daerah sekitar yang ditandai dengan warna kuning kecoklatan hingga ungu. Kontras warna tersebut memiliki rentang nilai chargeability yang tinggi berkisar antara 4,5-16,1 msec. Diduga warna yang kontras tersebut menunjukkan adanya anomali bijih besi. Selanjutnya, dilakukan pengirisan secara horisontal yang kemudian di proyeksinya tiap layer berdasarkan elevasinya. Berikut merupakan pengirisan horisontal yang divisualisasikan tiap layer berdasarkan elevasinya.

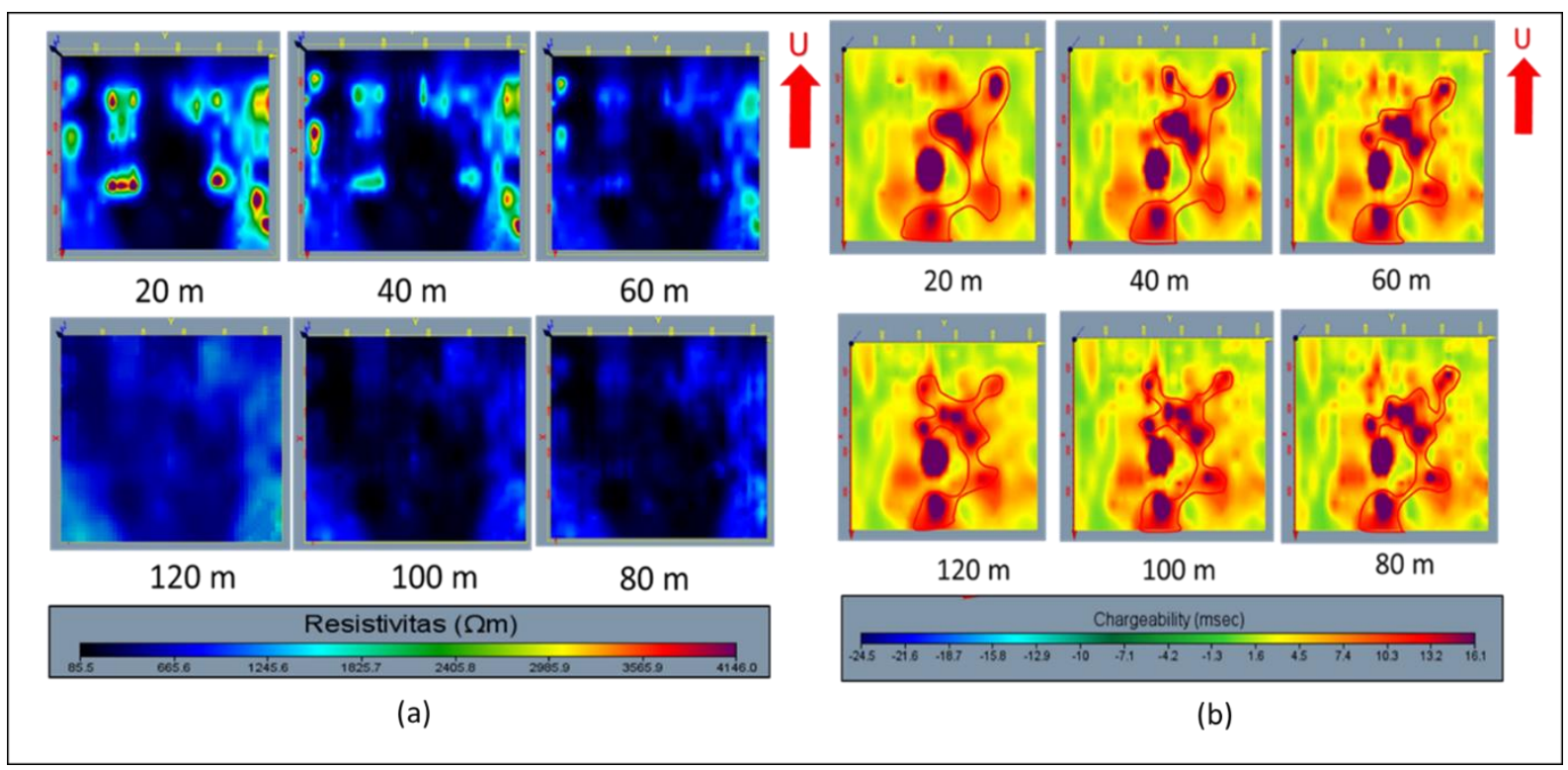

Gambar 9. Irisan horisontal resistivitas (a) chargeability (b) berdasarkan elevasi

Pada model terlihat adanya distribusi nilai resistivitas yang rendah ditandai dengan warna biru tua hingga biru muda dengan rentang nilai resistivitas berkisar antara 85,5-1246 $\Omega \mathrm{m}$. Warna tersebut diduga mengandung bijih besi terlihat pada layer 1 sampai layer 3 yang menunjukan warna biru sangat pekat. Pada layer 4 sampai layer 6 warna biru tersebut terlihat semakin samar dan menyebar. Berdasarkan model irisan chargeability berdasarkan elevasi, keberadaan bijih besi ditandai dengan daerah yang memiliki nilai chargeability tinggi dengan rentang warna kuning kecoklatan hingga ungu. Warna tersebut memiliki rentang chargeability berkisar antara 4,5-16,1 msec. Pada irisan layer chargeability menunjukan titik penyebaran bijih besi di daerah penelitian yang tersebar hingga elevasi ke 120 dan penyebarannya mengarah ke timur laut. 


\section{KESIMPULAN}

Berdasarkan hasil analisis dan interpretasi melalui model 2-Dimensi dan 3-Dimensi yang telah dikorelasikan dengan nilai referensi resistivitas dan chargeability serta kondisi geologinya didapatkan kesimpulan sebagai berikut:

1. Hasil analisis dan interpretasi yang telah dilakukan pada model 2-Dimensi menunjukan keberadaan bijih besi di daerah "A" Provinsi Kalimantan Selatan yang ditemukan sebanyak 16 buah lintasan diantaranya lintasan Q, P, O, N, M, V, L, K, W, J, I, H, G, F, E, dan D yang ditandai dengan rentang nilai resistivitas berkisar antara 85,5-1246 $\Omega \mathrm{m}$ dan rentang nilai chargeability berkisar antara 4,5-16,1 msec.

2. Berdasarkan model 3-Dimensi resistivitas dan chargeability-nya penyebaran bijih besi di daerah "A" Provinsi Kalimantan Selatan terlihat dibeberapa titik yang menyebar hingga evelasi ke 120 yang mengarah ke arah timur laut.

\section{REFERENSI}

[1] Amuzigi. [Online]. Available: https://www.amuzigi.com/2015/11/geologi-lembar-banjarmasinkalimantan.html.. [Accessed 12 Juli 2018].

[2] W, Lowrie, Fundamentals of Geophysics Second Edition, New York: Cambridge University, 2007.

[3] Eddy, Hadrian, "Pemodelan Data IP-Resistivity dan MAgnetik untuk Melokalisir Daerah Endapan Nikel Laterit di Daerah "LTD" SUlawesi Tenggara," Universitas Indonesia, Jakarta, 2010.

[4] M, Loke, "Tutorial: 2-D and 3-D Electrical Imaging Surveys," [Online]. Available: www.geoelectrical.com.

[5] W, Telford; L, Geldart; R, Sherrif, Applied Geophysocs Second Edition, 1990: New York: Press Syndicate of The University of Cambridg.

[6] Muhammad, Nafian, "Identifikasi Mineral Bijih Besi dengan Menggunakan Mteode Induced Polarization di Daerah Oku Selatan, Sumatera Selatan," in Prosiding Seminar Nasional E-Journal (SNF 2015), Jakarta, 2015.

[7] Kartika, Yuni, "Pemodelan 3-Dimensi Data Induced Polarization untuk Mengidentifikasi Bijih Besi di Daerah "A"Kabupaten Tanah Laut,," Unversitas Islam Negeri, Jakarta, 2017. 